\title{
Gas Chromatography-Mass Spectroscopy and Histopathological Effects of Methanol Leaf Extract of Uvaria chamae on the Midgut of Sitophilus zeamais
}

\author{
Diligent Oboho ${ }^{*}$, Samson Oyebadejo ${ }^{2}$, Innocent Edagha ${ }^{5}$, Peace Ubulom ${ }^{4}$, Basil Ita $^{3}$, Akwaowo Nelson ${ }^{4}$, Akaninyene \\ Akpan $^{4}$ and Joseph Eyo ${ }^{1}$ \\ ${ }^{1}$ Department of Zoology and Environmental Biology, University of Nigeria, Nsukka Enugu State, Nigeria \\ ${ }^{2}$ Department of Biotechnology, Molecular Pathology Laboratory, Shri Jagdish Prasad Jhabarmal Tibrewala University, \\ Jhunjhunu, Rajasthan 333001, India \\ ${ }^{3}$ Department of Chemistry, University of Uyo, Nigeria \\ ${ }^{4}$ Department of Animal and Environmental Biology, University of Uyo, Nigeria \\ ${ }^{5}$ Department of Human Anatomy, University of Uyo, Nigeria \\ *For Correspondence: sweetdili4life@yahoo.com \\ Received 05 August 2021; Accepted 25 September 2021; Published 15 December 2021
}

\begin{abstract}
The present study was carried out to assess the effect of methanol leaf extract of Uvaria chamae using Gas ChromatographyMass Spectrum (GC-MS) to determine the phytochemicals present and its effect on the histology of midgut of maize weevil, Sitophilus zeamais. Insects were administered with $10 \mathrm{mg} / \mathrm{kg}$ of the plant extract using diffusion method where insects were put in a petri dish containing various concentrations and observed to see the stage they begin to die due to toxicity and observed for $5 \mathrm{~min}$. They were collected into foil processing paper and fixed in Bouins fluid for $24 \mathrm{~h}$, repacked after $24 \mathrm{~h}$ and folded in fresh foil immersed in buffered formalin for histopathological studies. Result revealed that a severe degeneration de-arrangement of the respiratory tract epithelial lining, secretory lining cells and gastrointestinal layers with the destruction of the muscular layer when compared with the control. The methanol leaf extracts of $U$. chamae were preliminary screened for the phytochemicals. The extract shows the presence of cardiac glycosides, saponin, steroids/terpenes, flavonoids, alkaloids and phenols. GC-MS analysis of the extract showed the presence of 2-nitrobenzaldehyde (4.00), malic acid (2.04), L-aspartic acid (2.00), 1, 1, dimethylhydrazine (1.86), Cedrandiol (1.75), 2-amino-4-(2-methylpropenyl)-pyrimidin-5-carboxylic acid (1.56), thiirane (1.54), mercaptoethanol (1.11) and some minor compounds. The findings indicated that methanol extract of $U$. chamae is rich in phytocompounds having biological activities on the midguts' histology of $S$. zeamais. Therefore, it is recommended as an alternative for the synthetic insecticide used by farmers for the preservation of stored grains. (C) 2021 Friends Science Publishers
\end{abstract}

Keywords: Phytochemistry; GC-MS analysis; Histopathology; Sitophilus zeamais; Uvaria chamae

\section{Introduction}

Man grieves significantly both in agriculture and health due to the attack of the insect population. In agriculture, insects disturb growing crop parts and cause severe damage to stored products, leading to a loss in revenue. Insects are the invertebrate group's most essential living organisms, beneficial to humans and other species as well as harmful, causing diseases. The adjustable tropical biotopes provide a perfect environment for many arthropods, mainly insects. Botanical insecticides as undoubtedly used in crop protection are possibly likened to have started when agriculture began (Thacker 2002).

Extracts from local plants, used alone or in mixtures, have conventionally been used in Africa as crop protection agents. The combination of efficiency, speediness of action, easiness of use, and low cost of manmade insecticides has led many botanicals in most developed countries to near oblivion. However, Twenty years after manmade insecticides were decisively enshrined in 'modern' agricultural invention, the reported and so-called problems of general environmental degradation, harmfulness to non-target organisms, most significantly, adverse effects on human health led to a reappearance of interest in 'natural' pest control measures, including extended searches for new sources of plant insecticides. Consequently, several reports on the use of phytochemicals to control the hazard from insects exist (Regnault-Roger 2005; Isman 2006).

Uvaria chamae Beauv is a part of the Annonaceae family. It is commonly known as 'bush banana' or 'finger

To cite this paper: Oboho D, S Oyebadejo, I Edagha, P Ubulom, B Ita, A Nelson, A Akpan, J Eyo (2021). Gas Chromatography-Mass Spectroscopy and histopathological effects of methanol leaf extract of Uvaria chamae on the midgut of Sitophilus zeamais. Intl J Agric Biol 26:695-701 
root.' Additionally, the leaves are arranged with simple leaf structures, lanceolate in the shape of a whole lamina and net veined. Leaves are stipulated, leaf apex cuminate and the vestiture of the leaf is glabrous (Bongers et al. 2005). It is a climbing plant found primarily in West Africa's tropical rainforest (Okwu 2004). It's common in Nigeria's savannas and rain forests, as well as other African countries. Among the Igbos, Hausas and Yorubas respectively, it is called "Mmimiohia," "Kaskaifi," and "Akisan" (Adetunji 1999; Ogueke et al. 2007). U. chamae is known for its medicinal and nutritional value. However, Okwu and Iroabuchi (2009), reported that extracts of $U$. chamae are exhibits mutagenic effect. However, there are less research outcomes on its use as a natural insecticide. The aim of this work was to carry out the phytochemical constituents of the plant using Gas Chromatography-Mass spectroscopy and to evaluate the effect of the extracts on histology of the insect's midgut.

\section{Materials and Methods}

\section{Collections and identification of plant materials}

The fresh leaves of Uvaria chamae were obtained from Faculty of Pharmacy Medicinal Farm of University of Uyo, Akwa Ibom State and validated by a taxonomist in the Department of Botany and Ecological Studies, University of Uyo. Voucher specimens with number: UUH/3687 was deposited in their herbarium for further referencing.

\section{Rearing of test organisms}

To provide comparable age weevils for the experiment, $S$. zeamais cultures were established. A total of ten $(10 \mathrm{~kg})$ maize seeds were purchased and cleaned to remove any seeds with visible damage. To prevent potential field infestation, the clean seeds were kept in a sealed container in the fridge at $4^{\circ} \mathrm{C}$ for a month. Seeds were placed in soft bags and stored at room temperature for two weeks. Sexes of unruffled $S$. zeamais were determined by probing the snout of pestinfested corn grains. Females have a longer and thinner snout, while males have a shorter and fatter snout. Furthermore, females have smooth bumpy bodies, whilst males have rough bodies (Kranz et al. 1977). The insects were cultured on clean seeds, with 100 weevils per $400 \mathrm{~g}$ of seeds in each jar. To allow airing and prevent weevil escape, the jar was covered with muslin cloth and secured with a rubber band and kept at room temperature. All parent weevils were removed from each jar seven days after oviposition (Walgenbach et al. 1983). The dimorphic rostral characteristics were used to separate the sexes (Halstead 1963; Odeyemi and Daramola 2000; Adedire 2001). The jars were placed in an insect rearing cage kept in the Entomology Laboratory, Department of Animal and Environmental Biology, University of Uyo, Uyo. Newly emerged, two day-old insects was used for the experiment.

\section{Preparation of plant powder and extract}

After collection, the plant leaves were washed and chopped into pieces and room dried to a constant weight. Using a power-driven blender (Braum Multiquick Immersion Hand Blender, B White Mixer MR 5550CA, Germany), the dry plants were melded into fine powder and then kept in an airtight container pending use. The crude leaf extracts were then prepared using standard procedures as outlined by (Fatope et al. 1999; Mukhtar and Huda 2005; Santana et al. 2013). This involved soaking $50 \mathrm{~g}$ of the powder for $48-72$ $\mathrm{h}$ at room temperature in 95 percent methanol. This was followed by filtrate evaporation using a rotatory evaporator to obtain the crude extract.

\section{Phytochemical analysis of the plants}

The initial phytochemical screening of the different plants was carried out in Pharmacognosy Laboratory of University of Uyo, Akwa Ibom State using the standard procedures as described by (Harborne 1984; Evans 2002; Kokate et al. 2008; Prashant et al. 2011).

\section{Gas chromatography-mass spectrometry analysis}

A GC Clarus 500 Perkin Elmer system and gas chromatograph were interfaced with a mass detector (Turbo mass gold Perkin Elmer) according to Mishra et al. (2015) and Hema et al. (2010) (GC-MS). Column: Elite-5MS (5 percent diphenyl/95 percent dimethyl poly siloxane), $30 \mathrm{x}$ $0.25 \mathrm{~mm} \times 0.25 \mathrm{~mm}$ df, Carrier gas: Helium (99.999 percent) with constant flow rate of $1 \mathrm{~mL}$ per min, (Split ratio: 10:1), Sample Injection volume $2 \mathrm{~L}$, Software: Turbo mass 5.2, Oven operating in electron impact mode at $70 \mathrm{eV}$, oven temperature was fixed from $110^{\circ} \mathrm{C}$ (isothermal The injector was set to $250^{\circ} \mathrm{C}$, the ion source to $280^{\circ} \mathrm{C}$, and the total GC run time was $36 \mathrm{~min}$. The GC-MS was conducted in MultiUser Science Research Laboratory, Department of Chemistry, Ahmadu Bello University (ABU) Zaria, Kaduna, Nigeria.

\section{Determination of $\mathrm{LC}_{50}$}

The acute toxicity $\left(\mathrm{LC}_{50}\right)$ of the extract of the extract types used in this study were established using the method of Ousman et al. (2007) and Abbott (1925) where LC $\mathrm{C}_{50}$ of the extract types were obtained during preliminary studies until a concentration that will have effects $50 \%$ of the tests after 24 $\mathrm{h}$ was obtained.

\section{Histopathological assay of insects}

Using the method of Humason (1979), insects were administered with $10 \mathrm{~kg}$ the plant extract and observed for 5 min using diffusion method where insects were put in a petri 
dish containing various concentrations and observed to see the stage they begin to die due to toxicity. They were collected into foil processing paper and fixed in Bouins fluid for $24 \mathrm{~h}$, repacked after $24 \mathrm{~h}$ and folded in fresh foil immersed in buffered formalin for histopathological studies. After $48 \mathrm{~h}$ of fixations, samples were labeled according to the groups and process to paraffin wax by passing the basket of insects through $10 \%$ formal saline for $2 \mathrm{~h} .1 \mathrm{~h}$ in 3 changes of alcohol for dehydration ranging from 70 to $100 \%, 2$ changes of xylene for clearing, 2 changes of melted paraffin wax at $56^{\circ} \mathrm{C}$ for impregnation for $2 \mathrm{~h}$, samples were embedded in melted paraffin wax to create support for the tissues in the embedding cassettes. Then microtomy was carried out using Rotary Microtome by sectioning the embedded tissues at 5 $\mu \mathrm{m}$ and mounted the cut sections in ribbons from water bath on the labeled glass slide, drained of excess water, allowed to dry using hot plate and stained with hematoxylin and Eosin technique by dewaxing with xylene, taking the section to water, by passing through descending grade of alcohol, stained for nuclear content in hematoxylin for $10 \mathrm{~min}$, washed in water, differentiate in $1 \%$ acid alcohol and blue in saturated solution of lithium carbonate solution, washed in water and counter stained briefly in eosin, for $3 \mathrm{~min}$, then section were washed briefly and dehydrated, cleared in xylene, mounted with DPX, cover-slipped and observed under digital microscope for pathological changes.

\section{Results}

To examine the significance of some therapeutic plant, the first step is to screen for its phytochemicals, as it gives a wide knowledge with respect to the type of the compounds present in it. In the current study, the methanol leaf extracts of $U$. chamae were preliminary screened for the phytochemicals. The extract shows the presence of cardiac glycosides, saponin, steroids/terpenes, flavonoids, alkaloids and phenols as shown in Table 1.

GC-MS: Compound's name, molecular formulae, molecular weight, peak area and retention time of the bioactive compounds were established. The relative proportion amount of each constituent was calculated by relating its average peak area to the total mass. The results of Gas Chromatography-Mass Spectroscopy of the extracts of $U$. chamae are as shown on Table 2. The extracts of $U$. chamae showed eight (8) major compounds: Thiirane [RT40.712, Peak Percentage 1.539\%], 1,1, dimethylhydrazine [RT-41.115, Peak Percentage-1.861\%], malic acid [RT91.304, Peak Percentage- 2.040\%], 2-amino-4-(2methylpropenyl)-pyrimidin-5-carboxylic acid [RT-84.846, Peak Percentage-1.554\%], L-aspartic acid [RT-85.846, Peak Percentage- $2.001 \%$ ], 2- nitro benzaldehyde [RT-86.505, Peak Percentage- 3.903\%], Cedrandiol [RT-87.055, Peak Percentage- 1.751\%] and Mercaptoethanol [RT- 88.300, Peak Percentage- $1.115 \%$ ]. The phytochemicals from the extract are known to control insects by eroding the cuticle layer and causing dehydration. These phytochemicals are known to block the spiracles of insect and causing death by asphyxiation hence, the insecticidal efficacy of the plant.

Histological section of the $S$. zeamais administered with $10 \mathrm{mg} / \mathrm{kg}$ extract concentration of Uvaria chamae treatment at magnification X400 revealed severe de-arrangement of the respiratory, secretory and gastrol intestinal layer with destruction of the muscular layer when compared to the control group (Fig. 1a, b). The effect observed were the parting of the epithelial cells from the basement membrane with mutilation of the peritrophic membrane.

\section{Discussion}

The preliminary phytochemical screening of the plant extract of Uvaria chamae, revealed the presence of alkaloids, saponins, tannins, flavonoids, phenols and cardiac glycosides. This result was in agreement with the report of Udoh et al. (2019) who reported similar result from the crude extracts of $U$. chamae against wound isolated strains of Pseudomonas aeruginosa and Proteus mirabilis. Okokon et al. (2006), Okon et al. (2013), Kone et al. (2015), also reported similar result from the ethanolic root extract of $U$. chamae for its antibacterial, haematological and in vivo antimalarial activities respectively. Folawewo et al. (2017) and Bassey et al. (2014) who carried out a phytochemical screening of some methanolic plants extracts also found tannins, flavonoids, alkaloids and saponins to be the most abundant phytochemical present. Anthraquinone was not present in this study, while Phlobotannins was moderately present. The report of this study was in agreement with the results of Ekanem et al. (2016), Ebana et al. (2016) who carried out the phytochemical screening of extract of $L$. africana and $H$. africana and reported no trace of anthraquinone and moderately presence of Phlobatannins.

The study of organic chemicals found in plants, as well as their actions, has grown in popularity. GC-MS is an ideal technique for qualitative study of volatile and semi-volatile bioactive chemicals because it combines the best separation technique (GC) with the best identification technique (MS) (Grover and Patni 2013). The identified compounds possess some important biological potentials for future insecticide development especially those of botanical origin with low residual effects in the environment and low mammalian toxicity. Insecticides disrupt the natural functions of certain cells, making it harder for insects to survive. Many researchers have investigated the impact of different insecticides on the gut of insects from various orders, such as Orthoptera (Singh 1990).

Histopathologically, evidence of disintegration of columnar epithelial cells and severe detachment of cells from their basement membrane, in addition to nuclear degeneration, cytoplasmic material granulation, and vacuolization was observed in this study. This is similar to the work by Rawi et al. (2011) who stated that the larval midgut of $S$. littoralis had undergone histological changes when treated with Azadirachta indica and Citrulus colocynthesis 
Oboho et al. / Intl J Agric Biol, Vol 26, No 6, 2021

Table 1: Qualitative phytochemical analysis of the different extracts

\begin{tabular}{lll}
\hline & U. chamae & Test \\
\hline Anthraqunones & - & Borntrager \\
Steroids/terpenes & + & Liebermann- Burchard \\
Cardiac glycoside & + & Keller-kiliani, Salkowsiki \\
Saponin & + & Frothing, Fehling solution, $\mathrm{Na}_{2} \mathrm{CO}_{3}$ \\
Tannins and Phenols & + & Ferric Chloride, Pb acetate \\
Flavonoids & + & NaOH, Mayer, Wagner \\
Alkaloids & + & NaOH, Shinda \\
Phlobatannins & + & Dragendoff, Mayer, Wagner
\end{tabular}

Table 2: Chemical composition of methanol extract of $U$. chamae

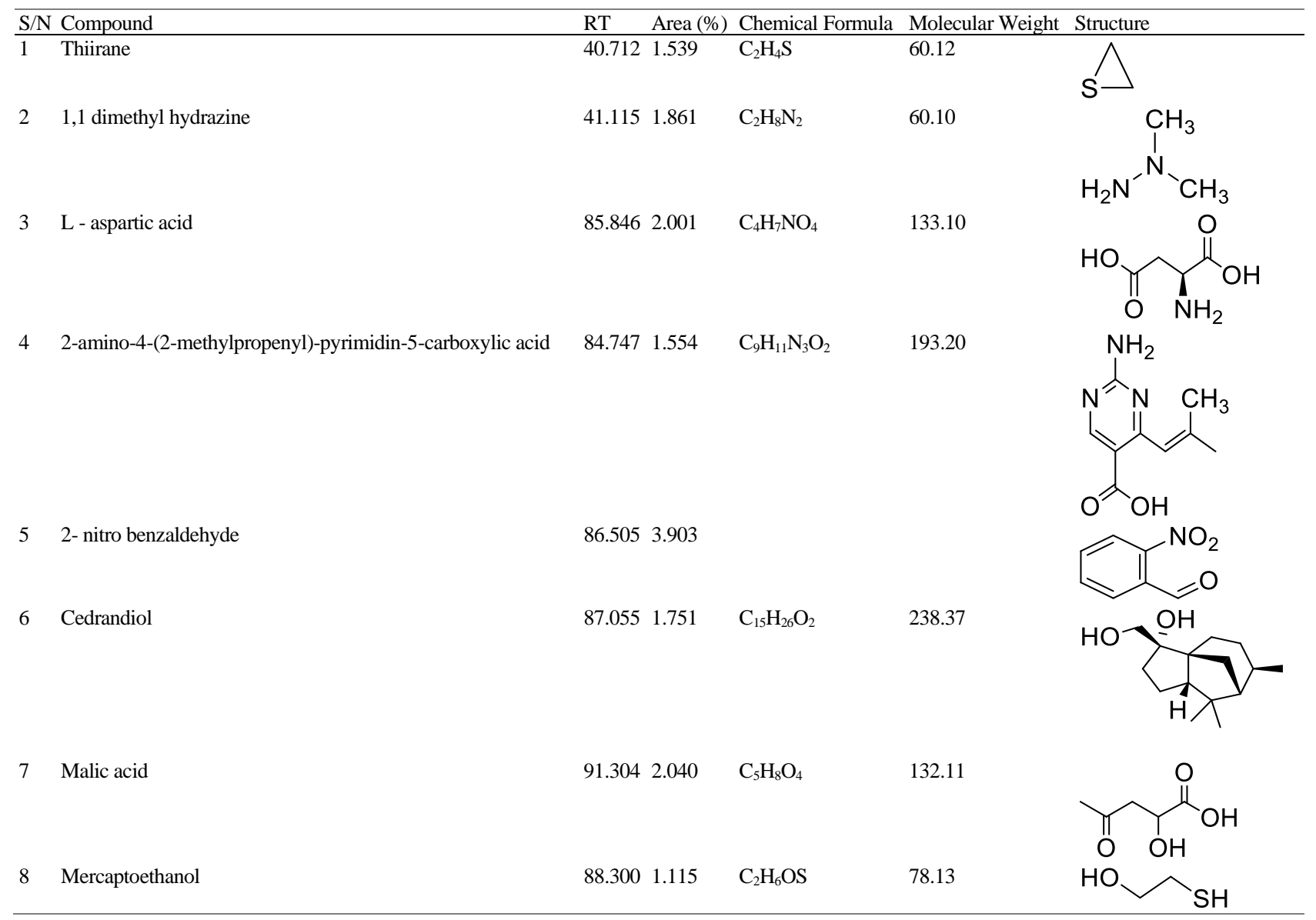

characterized with ep ithelial lining de-arrangement, necrosis and vacuolisation resulted from cell elongation and molecular decomposition of the nuclear and cytoplasmic constituents. Also, after 48 and $72 \mathrm{~h}$, the brush border and some epithelial cells were apically degenerated, and the majority of the cells completely disintegrated and vacuolated, according to Assar and El-Sokby (2003) who observed that the water extract of Eichlornia crassipes had a severe effect on larval midgut as the brush border and some epithelial cells were apically degenerated. The digestive system of insects is well known as one of the primary physiochemical barriers to numerous poisons and pathogenic agents. The gut is the key organ responsible for food digestion, assimilation, and absorption; any abnormalities in the gut region could impair the insect pests' growth and development, as well as their survival. The result of this study showed absorptive epithelial linings, shrunken nuclei and slanted epithelium when treated with extracts likened to control. Similar results were obtained by Prasad and Roy (2011), when completely shrunken midgut tissues with shrunken columnar epithelial cells and withered nuclei was reported in $H$. armigera fed with diet containing ethanol leaf extracts of Lantana camara. It also confirmed the work by Adel et al. (2010) who observed histological effects of Artemisia monosperma extract on 

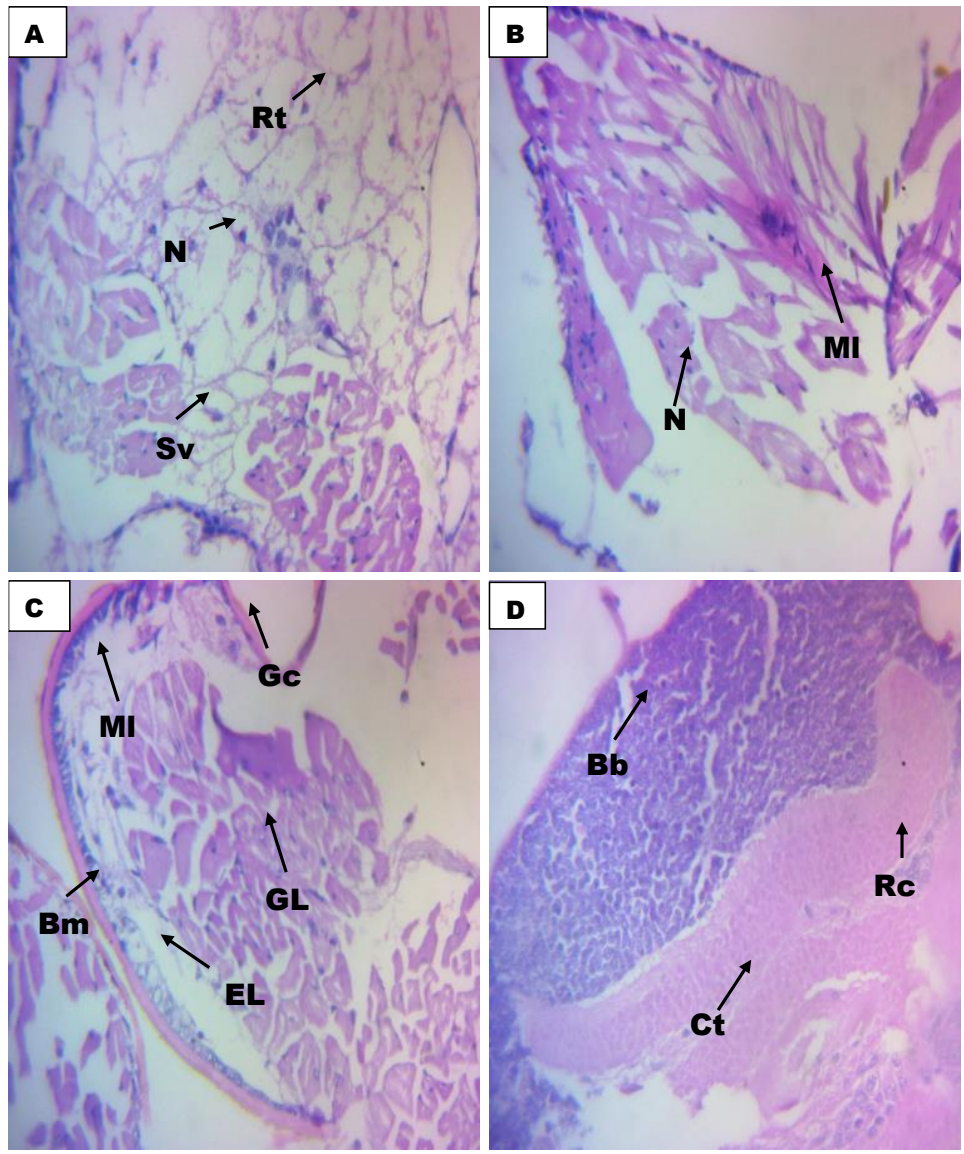

Fig. 1a: (Control) Sitophilus zeamais

Photomicrographs of Weevils without treatment at magnification $\mathrm{x} 400$ stained with H\&E method

Keys: Epithelium Lining (EL), Basement membrane (BM), Regenerative Cells (Rc), Gut Lumen (GL), Muscular Layer (ML), Secretory Vesicles (SV), Goblet cells (Gc), Connective Tissue (Ct) Respiratory tract $(\mathbf{R t})$ and Nucleus $(\mathbf{N})$

$\mathbf{A}=$ Respiratory Tract, $\mathbf{B}=$ Muscle, $\mathbf{C}=$ Gastro-intestinal Tract and $\mathbf{D}=$ Excretory system

S. littoralis thereby resulting in the damage of the mid-gut epithelium. Also, the histological disturbances in the mid-gut cells of $S$. littoralis with vacuolization and destruction of nuclear contents were recorded. Degenerated columnar epithelial cells and detachment from the basement membrane was observed by Adel et al. (2010) when he treated it with crude extracts of Azadirachta indica and Citrullus colocynthis. The result was also similar to that of Mishra $e t$ al. (2015), who observed slight but distinctive disappearance and alteration of absorptive epithelial cells joined with reformed shape and structure when extract of Thevetia neriifolia was tested on Helicoverpa armigera early fourth instars larvae.

\section{Conclusion}

Following the chemical composition as illustrated by the GSMS Chorography and the histopathological destruction caused by the investigated plant insecticide, it suggests that this extract are capable of causing death of an insect when it enters into tissues in sufficient amounts. In conclusion, the extract exhibited good insecticidal efficacy for the control of Sitophilus zeamais. Since this plant preparation is non-toxic to the non-target organisms, ecologically safe and freely obtainable, it can be incorporated into integrated pest management programmes.

\section{Acknowledgements}

The authors like to thank the laboratory technicians (Celestina Nwankwo and Wesley Okorie) of the Department of Zoology and Environmental Biology, University of Nigeria, Nsukka; Mr. Kokoette Raymond of Chemistry Department, University of Uyo; Dr. Bashir Musa, Multi- User Science Research Laboratory, Ahmadu Bello University, Zaria for their dedications to this work.

\section{Author Contributions}

DO and JE designed and supervised the study. DO, SO and AN carried out the laboratory studies. DO, IB and AA wrote 

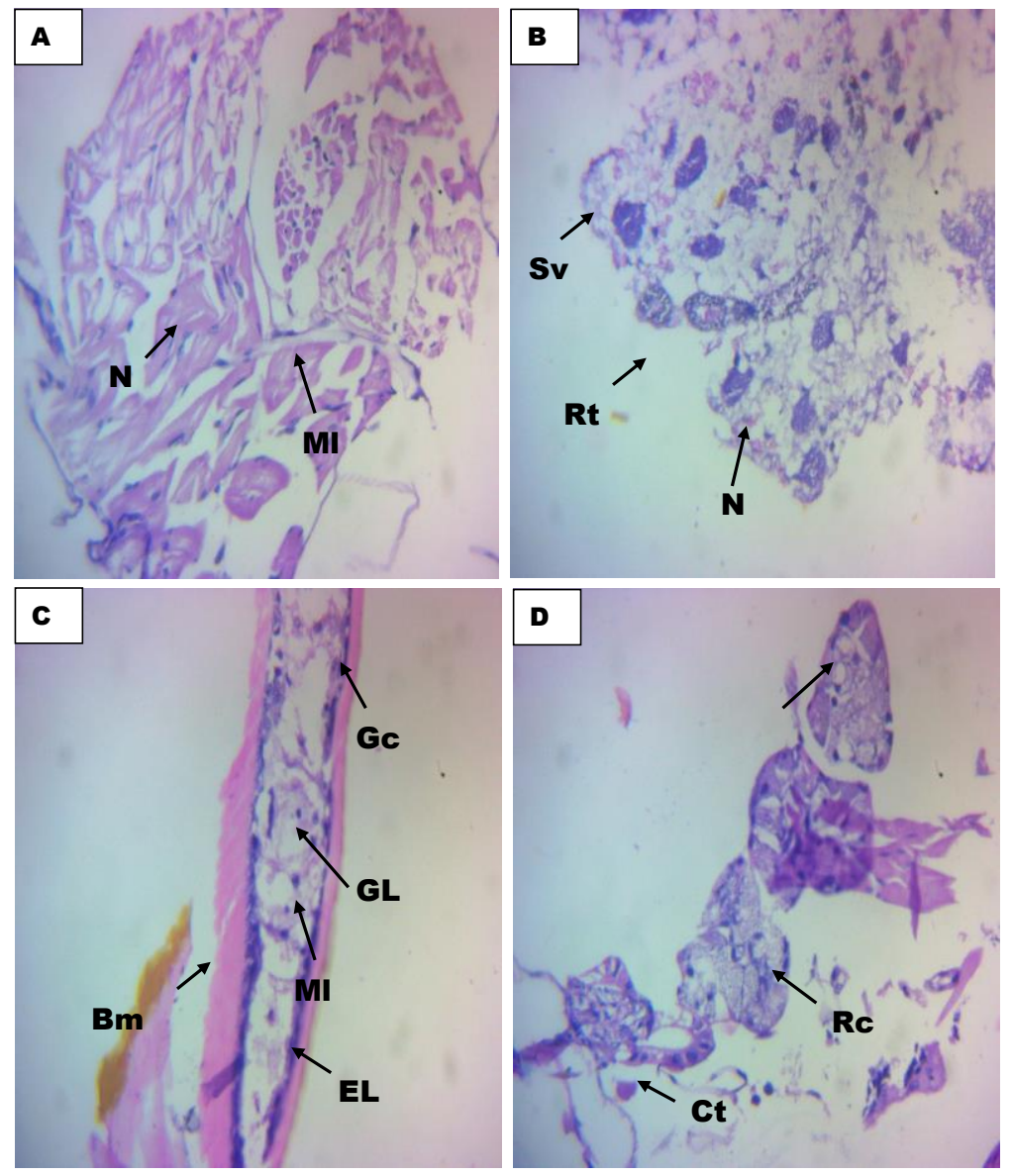

Fig. 1b: -2 (UC-CS)

Photomicrographs of maize weevils treated with $10 \mathrm{mg} / \mathrm{kg}$ of $U$, chamae at magnification $\mathrm{x} 400$ stained with $\mathrm{H} \& \mathrm{E}$ method

Keys: Epithelium Lining (EL), Basement membrane (BM), Regenerative Cells (Rc), Gut Lumen (GL), Muscular Layer (ML), Secretory Vesicles (SV), Goblet cells (Gc), Connective Tissue $(\mathbf{C t})$, Respiratory tract $(\mathbf{R t})$ and Nucleus $(\mathbf{N})$

$\mathbf{A}=$ Respiratory Tract, $\mathbf{B}=$ Muscle, $\mathbf{C}=$ Gastro-intestinal Tract and $\mathbf{D}=$ Excretory system

the first manuscripts; JE, DO, IB, IE and PU critically reviewed the manuscripts. All authors read and approved the final manuscripts.

\section{Conflicts of Interest}

The authors declared that there are no competing interests.

\section{Data Availability}

Data presented in this study will be available on a fair request to the corresponding author

\section{Ethics Approval}

Not applicable in this paper

\section{References}

Abbott WS (1925). A method of computing the effectiveness of an insecticide. J Econ Entomol 18:65-66
Adedire CO (2001). Biology, ecology and control of insect pests of stored grains. In: Pest of Stored Cereals and Pulses in Nigeria, pp:59-94. Ofuya TI, NES Lale (Eds). Dave Collins Publications, Akure, Nigeria

Adel MM, FM El-Hawary, NF Abdel-Aziz, EA Sammour (2010). Some physiological, biochemical and histopathological effects of Artemisia monosperma against the cotton leafworm, Spodoptera littoralis. Arch Phytopathol Plant Prot 43:1098-1110

Adetunji LK (1999). Great secret of Nature, p:256. Natural Links Centre, Lagos

Assar AA, MM El-Sokby (2003). Biological and histopathological studies of some plant extracts on larvae of Culex pipens (Diptera: Culicidae). $J$ Egypt Soc Parasitol 33:189-200

Bassey ME, EI Etuk, JU Ekpo (2014). Morphological diversity in the macrophyte genus Lasianthera (Icacinaceae) and the taxonomic implications. Liv Sys Sustain Dev 2:1-5

Bongers F, PME Parren, D Traore (2005). Forest Climbing Plants of West Africa: Diversity, Ecology and Management. CAB International, Publishing, Oxford, UK

Ebana RU, NU Asamudo, CA Etok, UO Edet, CS Onyebuisi (2016). Phytochemical screening, nutrient analysis and antimicrobial activity of the leaves of Lasianthera africana and Dennettia tripetala on clinical isolates. $J$ Adv Biol Biotechnol 8:1-9

Ekanem NG, HOC Mbagwu, GI Harry (2016). Phytochemical screening and hypoglycaemic activity of Lasianthera africana Beauv. (Aquifoliales: Stemonuraceae) leaf extract on diabetic rats. Braz J Biol Sci 3:293298 
Evans WC (2002). Trease and Evans' Pharmacognosy, $15^{\text {th }}$ edn. Elsevier, A Division of Reed Elsevier India Pvt. Limited, India

Fatope MO, H Ibrahim, Y Takeda (1999). Screening of higher plants reputed as pesticides using the brine shrimp lethality assay. Intl J Pharmacogn 31:250-254

Folawewo AD, AN Madu, FV Agbaje-Daniels, AO Faboyede, AR Coker (2017). Phytochemical screening and antibacterial activities of the root bark extracts of Hippocratea africana (Willd.) Loes. ex Engl. Eur J Med Plants 19:1-8

Grover N, V Patni (2013). Phytochemical characterization using various solvent extracts and GC-MS analysis of methanolic extract of Woodfordia fruiticosa (L.) Kurz. Leaves. Intl J Pharm Sci 5:291-295

Halstead DGH (1963). External sex differences in stored-products Coleoptera. Bull Entomol Res 54:119-134

Harborne JB (1984). Phytochemical Methods, $2^{\text {nd }}$ edn. Chapman and Hall, New York, USA

Hema R, S Kumaravel, C Sivasubramanian (2010). GC-MS study on the potentials of Syzygium aromaticum. Researcher 2:1-4

Humason GL (1979). Animal Tissue Techniques, $4^{\text {th }}$ edn. W.H. Freeman, San Francisco, USA

Isman MB (2006). Botanical insecticides, deterrents and repellents in modern agricultural and an increasingly regulated world. Annu Rev Entomol 51:45-56

Kokate CK, AP Purohit, SB Gokhale (2008). Pharmacognosy, $40^{\text {th }}$ edn Nirali Prakashan, India

Kone M, A Toure, K Outtara, A Coulibaly (2015). Phytochemical composition, Antioxidant and Antibacterial Activities of Root of Uvaria chamae P. Beauv (Annonaceae) used in Treatment of Dysentery in North of Cote d' Voire. Intl J Pharmacogn Phytol Res 7:1047-1053

Kranz J, H Schmutterer, W Koch (1977). Diseases, Pests, and Weeds in Tropical Crops. John Wiley and Sons, Incorporated, UK

Mishra M, KK Gupta, S Kumar (2015). Impact of the stem extract of Thevetia neriifolia on the feeding potential and histological architecture of the midgut epithelial tissue of early fourth instars of Helicoverpa armigera Hübner. Intl J Ins Sci 7:53-60

Mukhtar MD, M Huda (2005). Prevalence of Tinea capitis in primary school and sensitivity of etiological agents of Pisti astratiotes extracts. Nig J Microbiol 19:412-419

Odeyemi OO, AM Daramola (2000). Storage Practices in the Tropics: Food Storage and Pest Problems. Dave Collins Publications, Akure, Nigeria

Ogueke CC, JN Ogbulie, BN Anyanwu (2007). The effect of ethanolic and boiling water extracts of root-barks and leaves of Uvaria chamae on some hospital isolates. J Amer Sci 3:68-73
Okokon JE, BN Ita, AE Udokpoh (2006). The in vivo antimalarial activities of Uvaria chamae and Hippocratea africana. Ann Trop Med Parasitol 100:585-590

Okon JE, IR Udosen, EO Mbong (2013). Phytochemical screening and effect of ethanolic root extract of Uvaria chamae on haematological parameters on albino rats in Akwa Ibom State, Nigeria. Merit Res $J$ Environ Sci Toxicol 1:16-20

Okwu DE (2004). Phytochemicals and vitamin content of indigenous species of southeastern Nigeria. J Sustain Agric Environ 6:30-37

Okwu DE, F Iroabuchi (2009). Phytochemical composition and biological activities of Uvaria chamae and Clerodendoron splendus. J Chem 6:553-560

Ousman A, MB Ngassoum, JJ Essia-Ngang, LST Ngamo, R Ndjouvenkwu (2007). Insecticidal activity of spicy plant oils against Sitophilus zeamais in stored maize in Cameroun. Agric J 2:192-196

Prasad A, SB Roy (2011). Histoarchitectural alterations in the mid-gut tissues of fourth instar larvae of grain pod borer, Helicoverpa armigera (Hub) fed with leaf extract of plant, Lantana camara (L.). Intl J Pharm Biosci 2:613-620

Prashant T, K Bimlesh, K Mandeep, K Gurpreet, K Harleen (2011). Phytochemical screening and extraction: A review. Intl Pharm Sci 1:98-106

Rawi SM, FA Bakry, MA Al-Hazmi (2011). Biochemical and histopathological effect of crude extracts on Spodoptera littoralis larvae. J Evol Biol Res 3:67-78

Regnault-Roger O (2005). Effects of plant secondary chemicals on insects. $J$ Stored Prod 45:55-69

Santana PM, M Miranda, JA Payrol, M Silva, V Hernandez, E Peralta (2013). Gas Chromatography- Mass Spectrometry Study from the Leaves Fractions Obtained from Vernonanthura patens (Kunth) H. Rob. Intl J Org Chem 3:105-109

Singh MA (1990). Effect of some insecticide on the alimentary canal of surface grasshopper, Chrotogonus trachypterus Blanchard. (Pyrgomorhide: Orthoptera). Ind J Entomol 52:84-99

Thacker D (2002). Global Neem Update 2: 1. University Press, London

Udoh DI, US Ekong, BB Etang, NE Udo (2019). Qualitative assessment of Uvaria chamae crude extract against wound isolated strains of Pseudomonas aeruginosa and Proteus mirabilis alongside resistance and plasmid profiles determination of the isolates. Afr J Microbiol Res 13:520-530

Walgenbach CA, JK Phillips, DL Faustini, WE Burkholder (1983). Maleproduced aggregation pheromone of the maize weevil, Sitophilus zeamais, and interspecific attraction between three Sitophilus species. J Chem Ecol 9:831-841 